\title{
Hepatitis B Reactivation Rate and Fate Among Multiple Myeloma Patients Receiving Regimens Containing Lenalidomide and/or Bortezomib
}

\author{
Lenalidomid ve/veya Bortezomib İceren Tedavi Alan Multipı Myelom Hastalarında Hepatit B \\ Reaktivasyon Sıkı̆̆ı ve Sonuçları
}

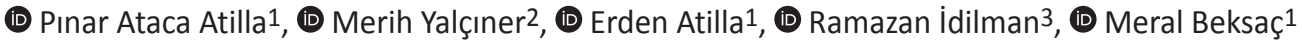 \\ ${ }^{1}$ Ankara University Faculty of Medicine, Department of Hematology, Ankara, Turkey \\ ${ }^{2}$ Ankara University Faculty of Medicine, Department of Internal Medicine, Ankara, Turkey \\ ${ }^{3}$ Ankara University Faculty of Medicine, Department of Gastroenterology, Ankara, Turkey
}

\section{Abstract}

\begin{abstract}
Objective: Reactivation of the hepatitis B virus (HBV) refers to an increase in HBV replication in a patient with inactive or resolved HBV. In this retrospective study, our aim is to present and compare HBV reactivation in multiple myeloma (MM) patients who received lenalidomide and/or bortezomib at any time during treatment, evaluate the factors associated with reactivation, and demonstrate the outcome of patients.
\end{abstract}

Materials and Methods: We evaluated $178 \mathrm{MM}$ patients who received lenalidomide $(n=102)$ and/or bortezomib $(n=174)$ during their treatment schedules. The $\mathrm{HBsAg}$, anti-HBc, anti-HBs, $\mathrm{HBeAg}$, and anti-HBe were detected by chemiluminescence by ARCHITECT Iab analyzers using commercially available kits (Abbott, USA). HBV-DNA titers were determined by quantitative PCR. The results were evaluated by IBM SPSS Statistics for Windows, Version 20.0 (IBM Corp., Armonk, NY, USA).

Results: HBV reactivation was diagnosed in 6 patients (3\%) after bortezomib and in 8 patients (8\%) after bortezomib and lenalidomide. Three of the patients in each group had $\mathrm{HBsAg}+$, $\mathrm{HBeAg}+$, AntiHBeAg-, AntiHBc-, and AntiHBS+ status, whereas 5 patients in the bortezomib- and lenalidomide-treated group and 3 patients in the bortezomib-treated group had $\mathrm{HBsAg}-$, $\mathrm{HBeAg}-$, AntiHBeAg-, AntiHBc-, and AntiHBS+ status prior to treatment. There were no statistical differences observed between $\mathrm{HBV}$ reactivation in the bortezomib-treated or bortezomib- and lenalidomide-treated groups in terms of age at diagnosis, sex, International Staging System subtype, frequency of extramedullary disease, dialysis requirement, or receiving of autologous stem cell transplantation. In patients who received antiviral prophylaxis, a higher incidence of $\mathrm{HBV}$ reactivation was detected in $\mathrm{HBsAg}$-positive patients compared to $\mathrm{HBsAg}$-negative patients $(4 / 4,100 \%$ vs. $2 / 7,29 \% ; p=0.045)$. The 3 -year and 5 -year
IIII Öz

Amaç: Hepatit B virüs (HBV) reaktivasyonu, HBV enfeksiyonunun inaktifleştiği veya iyileştiği hastalarda virüs replikasyonunun artışıdır. Bu geriye dönük çalışmada amacımız tedavilerinin herhangi bir döneminde lenalidomid ve/veya bortezomib alan multipl myelom (MM) hastalarında HBV reaktivasyonunu göstermek, reaktivasyonla ilişkili faktörleri ve sağkalımlarını değerlendirmektir.

Gereç ve Yöntemler: Tedavileri sırasında lenalidomid $(n=102)$ ve/ veya bortezomib $(n=174)$ alan $178 \mathrm{MM}$ hastası değerlendirilmiştir. ARCHITECT lab analiz cihazlarıyla $\mathrm{HBsAG}$, anti-HBc, anti-HBs, $\mathrm{HBeAg}$, anti-HBe piyasada bulunan kitlerle (Abbott, ABD) kemiluminesans yoluyla, HBV-DNA titreleri kuantitative PCR ile tespit edilmiştir. Sonuçların değerlendirilmesinde IBM SPSS 20.0 (IBM Corp., Armonk, NY, ABD) kullanılmıştır.

Bulgular: HBV reaktivasyonu, bortezomib kullanan 6 hastada (\%3) ile bortezomib ve lenalidomid alan 8 hastada (\%8) tespit edilmiştir. Tedavi öncesi iki gruptan 3 hastada $\mathrm{HBsAg}+, \mathrm{HBeAg}+$, AntiHBeAg-, AntiHBc-, ve AntiHBS+ saptanırken, bortezomib ve lenalidomid alan 5 hastada ve sadece bortezomib alan 3 hastada $\mathrm{HBsAg}_{-}, \mathrm{HBeAg}-$, AntiHBeAg-, AntiHBc-, ve AntiHBS+ saptanmıștır. Bortezomib veya bortezomib ve lenalidomid ile tedavi edilen gruplar arasında HBV reaktivasyonu ile tanı anındaki yaş, cinsiyet, evre, ekstramedüllar hastalık, diyaliz ihtiyacı veya otolog kök hücre nakil sıklığı arasında istatistiksel olarak fark saptanmamıştır. Antiviral profilaksi alan grupta, $\mathrm{HBsAg}$ pozitif olan hastalarda $\mathrm{HBsAg}$ negatif olan hastalara göre daha sık HBV reaktivasyonu tespit edilmiştir (4/4, \%100 ile 2/7, $\% 29 ; p=0,045)$. HBV reaktivasyonu gelişen ve gelişmeyen hastalarda 3 -yıllık ve 5 yıllık sağkalımlar benzerdir ( $\% 83$ ile $\% 84,073$ ile $\% 74$, $\mathrm{p}=0,84)$.

Sonuç: Sadece HBsAg pozitif hastalar değil HBsAg negatif hastalar da yakından takip edilmelidir.

๑Copyright 2019 by Turkish Society of Hematology

Turkish Journal of Hematology, Published by Galenos Publishing House

口耳37

Department of Hematology, Ankara, Turkey

Phone : +903125957099

E-mail : drpinarataca@gmail.com ORCID: orcid.org/0000-0003-4407-5461

Received/Geliş tarihi: March 08, 2019 Accepted/Kabul tarihi: July 31, 2019 


\section{Abstract}

overall survival rates were similar in patients with or without HBV reactivation ( $83 \%$ vs. $84 \%, 73 \%$ vs. $74 \%, p=0.84$ ).

Conclusion: Close follow-up is recommended for not only $\mathrm{HBsAg-}$ positive but also $\mathrm{HBsAg}$-negative patients.

Keywords: Hepatitis B reactivation, Bortezomib, Lenalidomide, Multiple myeloma, Antiviral therapy

\section{Öz}

Anahtar Sözcükler: Hepatit B reaktivasyonu, Bortezomib, Lenalidomid, Multipl myelom, Antiviral terapi

\section{Introduction}

The hepatitis B virus (HBV) represents a serious health concern worldwide. HBV is intermediately endemic in Turkey, where seropositivity of the hepatitis B surface antigen ( $\mathrm{HBsAg}$ ) has been reported to range between $2 \%$ and $7 \%[1,2]$. When there is an increase in HBV replication in a patient with inactive or resolved $\mathrm{HBV}$, this is referred to as reactivation of HBV. Commonly, it occurs in $\mathrm{HBsAg}$-positive cancer patients; $\mathrm{HBsAg}$-negative patients with positive anti-hepatitis B core antibody (anti-HBC) and/or anti-hepatitis B surface antibody (anti-HBs) also carry an increased risk $[3,4,5,6]$. Cytotoxic chemotherapy, monoclonal antibody treatments, and bone marrow transplantation have been demonstrated as risk factors for HBV reactivation $[7,8,9,10]$. HBV infection may result in severe hepatic dysfunction and fulminant hepatitis $[11,12]$. In current treatment guidelines, a prophylactic nucleoside analogue is recommended to be continued for at least 6 months after discontinuation of immunosuppressive therapy $[13,14]$.

Multiple myeloma (MM) is characterized by malignant proliferation of plasma cells. Bortezomib, a proteasome inhibitor that disrupts the cell-signaling pathways, has shown antimyeloma activity and has been recommended as a standard treatment in patients with newly diagnosed and relapsed MM [15]. Lenalidomide is a potent oral immunomodulatory drug with direct tumoricidal, anti-angiogenic, and immunostimulatory effects [16]. Both bortezomib and lenalidomide show remarkable activity in MM patients with manageable toxicity profiles. There are several case reports and studies on MM showing HBV reactivation under bortezomib treatment $[17,18,19]$, but the literature is scarce regarding HBV reactivation after lenalidomide treatment. In this retrospective study, our aim is to present and compare HBV reactivation in our MM patients who received lenalidomide and/or bortezomib at any time during treatment, evaluate the factors associated with reactivation, and demonstrate the outcome of patients.

\section{Materials and Methods}

We retrospectively included $178 \mathrm{MM}$ patients who were diagnosed between 2002 and 2015 at the Ankara University Faculty of Medicine's Department of Hematology. Informed consent was obtained from all participants. International Staging System (ISS) scores, counts of hemoglobin and lymphocytes, extramedullary involvement, and plasma cell percentage in bone marrow were recorded at the initiation of chemotherapy. The patients' data were analyzed via electronic medical records. All patients received lenalidomide and/or bortezomib during their treatment schedules, whether for induction, relapse, or post-induction maintenance.

Hepatitis B surface antigen ( $\mathrm{HBs} A \mathrm{~g})$, hepatitis B core antibody (anti-HBc), hepatitis B surface antibody (anti-HBs), hepatitis $\mathrm{B}$ e-antigen ( $\mathrm{HBeAg}$ ), and hepatitis B e-antibody (anti-HBe) were detected by chemiluminescence by ARCHITECT lab analyzers using commercially available kits (Abbott, USA) before each line of chemotherapy. HBV DNA titers were determined by quantitative PCR. Patients with active hepatitis B prior to chemotherapy were excluded from the study. If a patient was HBsAg-positive before chemotherapy or HBsAgnegative but positive for anti-HBc, $\mathrm{HBeAg}$, and/or anti$\mathrm{HBe}$ a prophylactic antiviral drug was administered during and for at least 6 months after chemotherapy. Hepatitis B serologies were closely monitored in patients who were $\mathrm{HBsAg}$-negative but seropositive for anti-HBc and/or anti-HBs, both before autologous peripheral stem cell transplantation and if liver enzyme abnormality occurred, to determine reactivation. Reactivation was defined as 1) loss of anti-HBs and reoccurrence of $\mathrm{HBsAg}$ in $\mathrm{HBsAg}$-negative and/or antiHBs-positive patients and 2) increase of HBV DNA level by at least a factor of 10 or an absolute count of HBV DNA reaching $1 \times 10^{9}$ copies $/ \mathrm{mL}$. Antiviral treatment was initiated as soon as reactivation was detected. None of the patients had received hepatitis $B$ vaccinations.

\section{Statistical Analysis}

The results were evaluated by IBM SPSS Statistics for Windows, Version 20.0 (IBM Corp., Armonk, NY, USA). All numerical values are given as medians with distribution ranges. We used the Pearson chi-square test or the Fisher exact test to compare categorical variables. The Kaplan-Meier method was used for survival curves. In evaluating the results, $p<0.05$ was considered statistically significant. 


\section{Results}

The median age of the 178 MM patients was 62 (range: 3486). The baseline characteristics of the study population are summarized in Table 1. At diagnosis, the mean lymphocyte count and hemoglobin concentration were respectively 1936/mL (range: 200-13200) and $11.5 \mathrm{~g} / \mathrm{dL}$ (range: 7-16). Subjects received a median of 3 lines of treatment (range: 1-7). First-line regimens were as follows: for 80 patients (45\%), bortezomib + cyclophosphamide + dexamethasone (VCD); 40 patients (22\%), vincristine + doxorubicin + dexamethasone (VAD); 21 patients (12\%), cyclophosphamide + dexamethasone (Cy-Dex); 15 patients (8\%), bortezomib + dexamethasone (VelDex); 12 patients (7\%), bortezomib + melphalan + prednisolone (VMP); 7 patients (4\%), melphalan + prednisolone + thalidomide (MPT); and 3 patients (2\%), lenalidomide + dexamethasone (Len-Dex). In total, 124 patients (70\%) were treated with highdose chemotherapy and underwent autologous hematopoietic stem cell transplantation (auto-HSCT). During the treatment period, 102 patients (57\%) received $25 \mathrm{mg} /$ day lenalidomide with dexamethasone or $10 \mathrm{mg} /$ day lenalidomide as a single agent; 174 patients (98\%) received $1.3 \mathrm{mg} / \mathrm{m}^{2}$ bortezomib in combination with dexamethasone, cyclophosphamide

\begin{tabular}{|l|l|}
\hline \multicolumn{2}{|l|}{ Table 1. Study population characteristics. } \\
\hline Variables & \\
\hline Age, $\mathbf{n}(\%)$ & $114(64 \%)$ \\
$<65$ years & $64(36 \%)$ \\
$\geq 65$ years & \\
\hline Sex, $\mathbf{n}$ (\%) & $102(57 \%)$ \\
Male & $76(43 \%)$ \\
Female & \\
\hline MM subtype, $\mathbf{n}(\%)$ & $28(16 \%)$ \\
IgA kappa & $13(7 \%)$ \\
IgA lambda & $76(43 \%)$ \\
IgG kappa & $34(19 \%)$ \\
IgG lambda & $13(7 \%)$ \\
Kappa light chain & $6(3 \%)$ \\
Lambda light chain & $8(4 \%)$ \\
Others (IgD, nonsecretory, biclonal) & \\
\hline International Staging System, $\mathbf{n}(\%)$ & $50(28 \%)$ \\
I & $55(31 \%)$ \\
II & $73(41 \%)$ \\
III & $87(49 \%)$ \\
\hline Extramedullary disease, $\mathbf{~ ( \% ) ~}$ & $91(51 \%)$ \\
\hline Yes & $178(100 \%)$ \\
No & $15(8 \%)$ \\
\hline Hypogammaglobulinemia, $\mathbf{n}(\%)$ & $163(92 \%)$ \\
\hline Yes & \\
\hline Dialysis requirement, $\mathbf{n}(\%)$ & \\
Yes & \\
No & \\
\hline
\end{tabular}

plus dexamethasone, lenalidomide plus dexamethasone, or melphalan plus prednisone. Bortezomib and lenalidomide were administered to 98 patients (55\%). Disease relapse was detected in 122 patients (69\%). During follow-up, 41 patients (23\%) had progressive disease and 37 patients (21\%) died. Herpes virus reactivation (herpes zoster) was detected in 15 patients (8\%), 2 of whom received lenalidomide and bortezomib.

Among all subjects, HBsAg was positive in 4 patients (2\%) at diagnosis. Among HBsAg-positive patients, 3 patients had HBV DNA levels of $>1000 \mathrm{IU} / \mathrm{mL}$. For prophylaxis, patients received either $100 \mathrm{mg}$ of lamivudine $(\mathrm{n}=2)$ or $245 \mathrm{mg}$ of tenofovir $(n=2)$ daily, which continued for 6 months after termination of treatment for MM, except in 1 patient who died of infection in the second month of chemotherapy. Among HBsAg-negative patients who were positive for anti-HBc, anti-HBe, or $\mathrm{HBeAg}$ $(\mathrm{n}=7), 6$ patients received $100 \mathrm{mg} /$ daily lamivudine, and 1 patient had entecavir at $0.5 \mathrm{mg} /$ daily for prophylaxis that was prolonged for 6 months after treatment of MM. All HBsAgnegative patients had HBV DNA levels of $<500 \mathrm{IU} / \mathrm{mL}$. No significant differences were observed in sex, age at diagnosis, ISS stage, subtype, frequency of extramedullary disease, or dialysis requirements between $\mathrm{HBsAg}$-positive and $\mathrm{HBsAg}$ negative patients.

Hepatitis B reactivation was observed in 14 patients (8\%). The patients' HBV and prophylaxis statuses at diagnosis are summarized in Table 2. The median time from diagnosis to hepatitis $B$ reactivation was 32 months (range: 2-78). Of 174 bortezomib-treated patients, 6 had HBV reactivation (3\%). HBV reactivation was detected in 8 patients out of the 98 patients who received lenalidomide and bortezomib (8\%). Reactivation developed in 4 patients (100\%) who were HBsAg-seropositive at diagnosis, while 10 patients (6\%) were initially $\mathrm{HBsAg}$-negative. $\mathrm{HBsAg}$-positive patients who received prophylaxis had significantly higher incidence of

\begin{tabular}{|c|c|c|c|}
\hline & $\begin{array}{l}\text { HBsAg+ } \\
\text { HBeAg+ } \\
\text { AntiHBeAg- } \\
\text { AntiHBc- } \\
\text { AntiHBS+ / } \\
\text { Prophylaxis (+), } \\
\text { n (\%) }\end{array}$ & $\begin{array}{l}\text { HBsAg- } \\
\text { HBeAg- } \\
\text { AntiHBeAg- } \\
\text { AntiHBc- } \\
\text { AntiHBS+ I } \\
\text { Prophylaxis } \\
\text { (-), n (\%) }\end{array}$ & $\begin{array}{l}\text { Total } \\
\text { reactivation, } \\
\text { n ( } \%)\end{array}$ \\
\hline $\begin{array}{l}\text { Bortezomib } \\
\text { (diagnosis) }\end{array}$ & $3(21 \%)$ & & $3(21 \%)$ \\
\hline $\begin{array}{l}\text { Bortezomib } \\
\text { (relapse) }\end{array}$ & & $3(21 \%)$ & $3(21 \%)$ \\
\hline Lenalidomide & $3(21 \%)$ & $5(38 \%)$ & $8(58 \%)$ \\
\hline Total & $6(42 \%)$ & $8(58 \%)$ & $14(100 \%)$ \\
\hline
\end{tabular}

\section{with reactivation.}


hepatitis $B$ reactivation than $\mathrm{HBsAg}$-negative patients (4/4, $100 \%$ vs. $2 / 7,29 \% ; p=0.045)$. The 3 -year and 5 -year overall survival (OS) was similar in patients with and without HBV reactivation ( $83 \%$ vs. $84 \%, 73 \%$ vs. $74 \%, p=0.84$ ) (Figure 1). Details of patients with HBV reactivation are given in Tables 3 and 4. Patient number 5 in Table 4 had HBV reactivation under lamivudine prophylaxis and died because of bacterial infection following 2 months of chemotherapy. Chemotherapies were suspended until liver function tests and HBV DNA levels were decreased.

Baseline characteristicsincluding MM subtype, extramedullary disease, median age, sex, ISS, incidence of herpes infection, and auto-HSCT did not differ between the bortezomib- and lenalidomide-treated vs. bortezomib-treated groups that had $\mathrm{HBV}$ reactivation. Lenalidomide treatment was interrupted in $4(50 \%)$ of the patients due to progression of disease. Except for 1 patient, all patients underwent autologous stem cell transplantation (ASCT), and 1 patient who received a second ASCT for a secondary refractory disease had progression to cirrhosis following high-dose melphalan. After treatment with tenofovir, HBV DNA titers decreased in all patients and became undetectable in 4 of the 8 patients. In patients treated with only bortezomib, all patients received dexamethasone, and 4 of 6 patients underwent ASCT. Progression of disease after bortezomib was detected in 2 patients. Among these 6 patients, 4 patients were treated with tenofovir (2 achieved HBV DNA negativity), and the other 2 were treated with lamivudine. The response could not be evaluated for patient number 5, because she died of infection within 2 months of the initiation of chemotherapy (Tables 3 and 4).

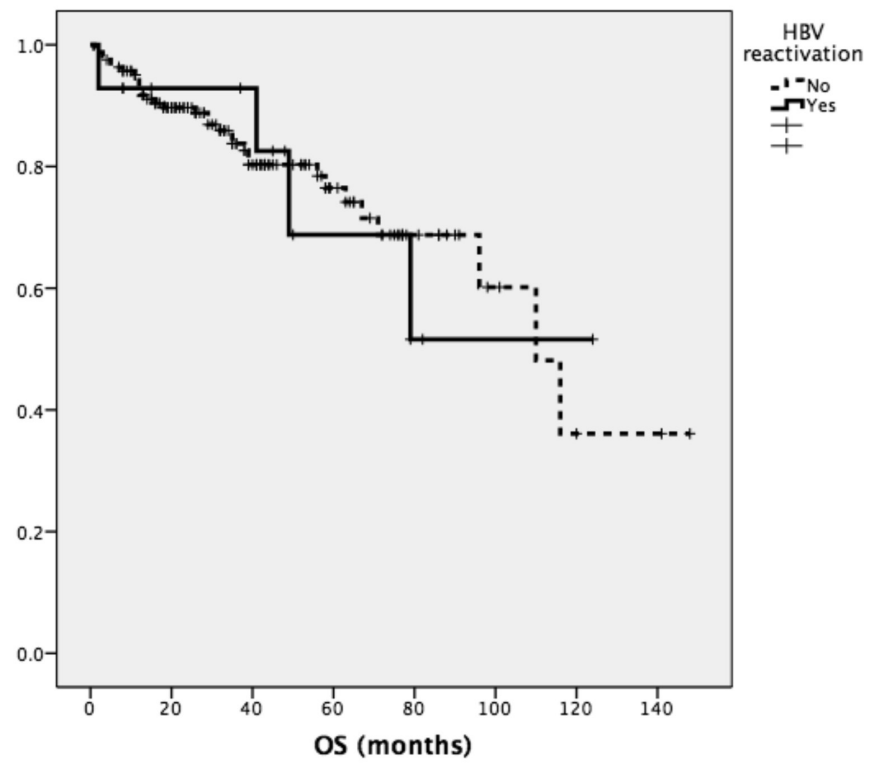

Figure 1. Comparison of overall survival in patients with or without hepatitis $B$ virus reactivation $(p=0.84)$.

OS: Overall survival, HBV: hepatitis B virus.

\section{Discussion}

Generally, HBV reactivation has been documented in $\mathrm{HBsAg-}$ positive cancer patients [20]. In one study, the rate of $\mathrm{HBsAg}$ seropositivity in $\mathrm{MM}$ cases was higher than in patients with acute leukemia [21]. Antiviral prophylaxis is the critical step in managing $\mathrm{HBsAg}$-positive patients undergoing systemic chemotherapy $[13,22]$. Clinical studies showed a reduction of HBV activation rate, severity of hepatitis, and mortality with prophylaxis $[23,24]$. The American Gastroenterological Association suggests antiviral drugs with high barriers to resistance rather than lamivudine for at least 6 months in high-risk patients [14]. Previously, in our experience, because HBV reactivation in a lamivudine-untreated group occurred 12 months after the individual's chemotherapy had been discontinued, lamivudine prophylaxis was maintained for a year following discontinuation of any chemotherapy $[25,26]$. The choice of lamivudine or a shorter duration of prophylaxis might have caused the HBV reactivation that occurred in all $\mathrm{HBsAg-}$ positive patients who received prophylaxis in this cohort. One patient with $\mathrm{HBV}$ reactivation died under lamivudine prophylaxis within 2 months of chemotherapy. Recent data have shown HBV reactivation in $\mathrm{HBsAg}$-negative lymphoma patients who received rituximab plus steroid combination chemotherapy $[3,4,27]$. Lee et al. [28] demonstrated HBV reactivation in 5.2\% of $230 \mathrm{MM}$ patients. All of these patients had HBsAg-negative/anti-HBcpositive serology. Similarly, we found that the incidence of HBV reactivation in $\mathrm{HBsAg}$-negative patients was 6\%. The preferred prophylaxis was lamivudine in $\mathrm{HBsAg}$-negative patients.

This is the first study of the recently developed agents lenalidomide and bortezomib in $\mathrm{MM}$, and we observed an incidence of HBV reactivation of $8 \%$. HBV reactivation after bortezomib was described in previous case reports $[17,18,19]$. Mya et al. [29] found an incidence of HBV reactivation of 5.5\% in $273 \mathrm{MM}$ patients after bortezomib and dexamethasone salvage therapy; one of the $\mathrm{HBV}$ reactivation cases was $\mathrm{HBsAg}$ negative initially. Li et al. [30] conducted one of the largest retrospective studies of HBV reactivation in patients who received regimens containing bortezomib. HBV reactivation was observed in $6 \mathrm{HBsAg}$-positive and $2 \mathrm{HBsAg}$-negative cases from a total of 139 patients. OS and progressionfree survival were shorter in $\mathrm{HBsAg}$-positive MM patients compared to $\mathrm{HBsAg-negative} \mathrm{patients}(p<0.01)$ [30]. We did not detect any survival advantage in $\mathrm{HBsAg}$-negative patients in our study. Bortezomib dysregulated the cell-mediated immunity that played an important role in the suppression of varicella zoster virus reactivation [31]. HBV is another DNA virus that remains dormant in human hosts. Bortezomib may promote HBV reactivation by altering the number and functions of CD8 T cells and CD56 NK cells [29]. In addition, MM itself causes immunodeficiency that involves various parts of the immune system, including $B$, dendritic, $T$, and NK 
cell dysfunction. HBV reactivation after lenalidomide has not been reported previously in the literature. König et al. [32] reported 10 varicella zoster virus or other complicated VSC/ herpes simplex virus infections from 93 MM patients who received lenalidomide-based chemotherapy, which may have resulted from the immunomodulation effects of lenalidomide. Since the patients in our study were heavily pretreated, and there was no control group assigned for patients not

\begin{tabular}{|c|c|c|c|c|c|c|c|c|}
\hline $\begin{array}{l}\text { Patient } \\
\text { No. }\end{array}$ & Sex/Age & Subtype/ISS & $\begin{array}{l}\text { Treatment lines/ } \\
\text { Response }\end{array}$ & $\begin{array}{l}\text { Hepatitis B } \\
\text { markers before } \\
\text { treatment/ } \\
\text { Prophylaxis }\end{array}$ & $\begin{array}{l}\text { Time to } \\
\text { reactivation } \\
\text { after } \\
\text { lenalidomide } \\
\text { withdrawal } \\
\text { (months) }\end{array}$ & $\begin{array}{l}\text { Hepatitis B } \\
\text { markers after } \\
\text { reactivation }\end{array}$ & $\begin{array}{l}\text { Antiviral } \\
\text { treatment/ } \\
\text { Response }\end{array}$ & OS/Outcome \\
\hline 1 & $\mathrm{M} / 56$ & Lambda/II & $\begin{array}{l}\text { VCD, ASCT, Len- } \\
\text { Dex/CR }\end{array}$ & $\begin{array}{l}\text { HBsAg-, } \\
\text { HBeAg-, } \\
\text { AntiHBeAg-, } \\
\text { AntiHBc-, } \\
\text { AntiHBS+l- }\end{array}$ & 11 & $\begin{array}{l}\text { HBsAg+, } \\
\text { HBeAg+, } \\
\text { AntiHBeAg-, } \\
\text { AntiHBc+, } \\
\text { AntiHBs- }\end{array}$ & $\begin{array}{l}\text { Tenofovir/ } \\
\text { HBV DNA } \\
\text { decreased }\end{array}$ & $\begin{array}{l}\text { 24/Alive, Liver } \\
\text { Bx: Ishak 4, } \\
\text { Stage } 1\end{array}$ \\
\hline 2 & $\mathrm{M} / 75$ & IgGKappa/II & $\begin{array}{l}\text { VMP, VP, ASCT, } \\
\text { Len-Dex/VGPR }\end{array}$ & $\begin{array}{l}\text { HBsAg-, } \\
\text { HBeAg-, } \\
\text { AntiHBeAg-, } \\
\text { AntiHBc-, } \\
\text { AntiHBS+/- }\end{array}$ & 18 & $\begin{array}{l}\text { HBsAg+, } \\
\text { HBeAg+, } \\
\text { AntiHBeAg-, } \\
\text { AntiHBc+, } \\
\text { AntiHBs- }\end{array}$ & $\begin{array}{l}\text { Tenofovir/ } \\
\text { HBV DNA } \\
\text { decreased }\end{array}$ & 46/Alive \\
\hline 3 & $\mathrm{M} / 61$ & IgGКарра/III & $\begin{array}{l}\text { VAD, Vel- } \\
\text { Dex, ASCT, } \\
\text { Lenalidomide, } \\
\text { Benda-Dex, } \\
\text { Pomalidomide- } \\
\text { Dex, ASCT/ } \\
\text { Progression } \\
\end{array}$ & $\begin{array}{l}\text { HBsAg-, } \\
\text { HBeAg-, } \\
\text { AntiHBeAg-, } \\
\text { AntiHBc-', } \\
\text { AntiHBS+l- }\end{array}$ & 5 & $\begin{array}{l}\text { HBsAg+, } \\
\text { HBeAg+, } \\
\text { AntiHBeAg-, } \\
\text { AntiHBc+, } \\
\text { AntiHBs- }\end{array}$ & $\begin{array}{l}\text { Tenofovir/ } \\
\text { HBV DNA } \\
\text { decreased }\end{array}$ & 37/Alive \\
\hline 4 & $F / 43$ & $\begin{array}{l}\text { IgALambda/ } \\
\text { III }\end{array}$ & $\begin{array}{l}\text { Cy-Dex, ASCT, } \\
\text { Vel-Dex, Len- } \\
\text { Dex, Carfilzomib/ } \\
\text { Progression }\end{array}$ & $\begin{array}{l}\text { HBsAg-, } \\
\text { HBeAg-, } \\
\text { AntiHBeAg+, } \\
\text { AntiHBc-, } \\
\text { AntiHBS+/ } \\
\text { Lamivudine } \\
\end{array}$ & 7 & $\begin{array}{l}\text { HBsAg+, } \\
\text { HBeAg+, } \\
\text { AntiHBeAg-, } \\
\text { AntiHBc+, } \\
\text { AntiHBs- }\end{array}$ & $\begin{array}{l}\text { Tenofovir/ } \\
\text { HBV DNA- }\end{array}$ & $\begin{array}{l}\text { 49/Exitus, } \\
\text { Disease } \\
\text { Progression }\end{array}$ \\
\hline 5 & $F / 62$ & $\begin{array}{l}\text { IgGLambda/ } \\
\text { III }\end{array}$ & $\begin{array}{l}\text { VAD, Vel-Dex, } \\
\text { ASCT, Thalidomide, } \\
\text { Lenalidomide, } \\
\text { Benda-Dexa, } \\
\text { Carfilzomib-Dexa/ } \\
\text { VGPR } \\
\end{array}$ & $\begin{array}{l}\text { HBsAg-, } \\
\text { HBeAg-, } \\
\text { AntiHBeAg-, } \\
\text { AntiHBc-', } \\
\text { AntiHBS+/- }\end{array}$ & 10 & $\begin{array}{l}\text { HBsAg+, } \\
\text { HBeAg+, } \\
\text { AntiHBeAg-, } \\
\text { AntiHBc+, } \\
\text { AntiHBs- }\end{array}$ & $\begin{array}{l}\text { Tenofovir/ } \\
\text { HBV DNA- }\end{array}$ & 79/Exitus \\
\hline 6 & $\mathrm{M} / 69$ & IgGKappa/III & $\begin{array}{l}\text { Vel-Dex, ASCT, } \\
\text { Len-Dex/CR }\end{array}$ & $\begin{array}{l}\text { HBsAg-, } \\
\text { HBeAg-, } \\
\text { AntiHBeAg-, } \\
\text { AntiHBc-, } \\
\text { AntiHBS+/- }\end{array}$ & 13 & $\begin{array}{l}\text { HBsAg+, } \\
\text { HBeAg+, } \\
\text { AntiHBeAg-, } \\
\text { AntiHBc+, } \\
\text { AntiHBs- }\end{array}$ & $\begin{array}{l}\text { Tenofovir/ } \\
\text { HBV DNA- }\end{array}$ & 67/Alive \\
\hline 7 & $F / 61$ & $\begin{array}{l}\text { IgGLambda/ } \\
\text { II }\end{array}$ & $\begin{array}{l}\text { VCD, ASCT, Len- } \\
\text { Dex/CR }\end{array}$ & $\begin{array}{l}\text { HBsAg-, } \\
\text { HBeAg-, } \\
\text { AntiHBeAg+, } \\
\text { AntiHBc-, } \\
\text { AntiHBS+/ } \\
\text { Lamivudine } \\
\end{array}$ & 13 & $\begin{array}{l}\text { HBsAg+, } \\
\text { HBeAg+, } \\
\text { AntiHBeAg-, } \\
\text { AntiHBc+, } \\
\text { AntiHBs- }\end{array}$ & \begin{tabular}{|l} 
Tenofovir/ \\
HBV DNA-
\end{tabular} & 21/Alive \\
\hline 8 & $F / 63$ & IgGKappa/III & $\begin{array}{l}\text { VAD, Vel-Dex, } \\
\text { MPT, DCEP, Len- } \\
\text { Dex, Benda-Dex }\end{array}$ & $\begin{array}{l}\text { HBsAg+, } \\
\text { HBeAg+, } \\
\text { AntiHBeAg-, } \\
\text { AntiHBc-, } \\
\text { AntiHBS+l } \\
\text { Lamivudine }\end{array}$ & 10 & $\begin{array}{l}\text { HBsAg+, } \\
\text { HBeAg+, } \\
\text { AntiHBeAg-, } \\
\text { AntiHBc+, } \\
\text { AntiHBs- }\end{array}$ & $\begin{array}{l}\text { Tenofovir/ } \\
\text { HBV DNA } \\
\text { decreased }\end{array}$ & 54/Alive \\
\hline \multicolumn{9}{|c|}{$\begin{array}{l}\text { ASCT: Autologous stem cell transplantation, Anti-HBc: hepatitis B core antibody, AntiHBe: hepatitis B e-antibody, Anti-HBs: hepatitis B surface antibody, Benda: bendamustine, CR } \\
\text { complete remission, Cy-Dex: cyclophosphamide + dexamethasone, DCEP: dexamethasone + cyclophosphamide + etoposide + cisplatin, HBsAg: hepatitis B surface antigen, HBeAg } \\
\text { hepatitis B e-antigen, Len-Dex: lenalidomide + dexamethasone, MPT: melphalan + prednisolone + thalidomide, VCD: bortezomib + cyclophosphamide + dexamethasone, VAD } \\
\text { vincristine + doxorubicin + dexamethasone, Vel-Dex: bortezomib + dexamethasone, VMP: bortezomib + melphalan + prednisolone, VGPR: very good partial remission. }\end{array}$} \\
\hline
\end{tabular}


receiving either bortezomib or lenalidomide, it is not clear whether the HBV reactivation was driven by bortezomib and/or lenalidomide. Multiple lines of treatment may cause severe immunosuppression that results in an increased risk of HBV reactivation [33].

Auto-HSCT was shown to be a risk factor for HBV reactivation in several reports. Uhm et al. [34] retrospectively analyzed changes in HBV serology prior to and following auto-HSCT and concluded that 6 of $129 \mathrm{HBsAg}$-negative MM patients became HBsAg-positive, possibly related to dysfunction of humoral immunity. Lee et al. [28] determined auto-HSCT to be an independent risk factor $(p=0.025)$ for HBV reactivation and suggested that regular monitoring should be considered in patients who underwent auto-HSCT [28]. However, we did not find a significant correlation between HBV reactivation and auto-HSCT.
HBV reactivation may be variable, from mildly clinical to hepatic failure. Development of fatal hepatitis following HBV reactivation was reported in CD20-positive lymphoma patients who received rituximab and steroid combination treatment $[7,27]$. Yoshida et al. [35] described HBV reactivation in $2 \mathrm{HBsAg}-$ seronegative MM patients resulting in liver damage. Similarly, one of our heavily pretreated patients with HBV reactivation had disease with liver damage progressing to cirrhosis following a second ASCT treatment.

\section{Conclusion}

We found that the incidence of HBV reactivation was notable in patients who received lenalidomide- and/or bortezomib-based chemotherapy. Most of the patients were heavily pretreated, which might have caused immune deficiencies. HBV reactivation was diagnosed in both $\mathrm{HBsAg}$-positive and $\mathrm{HBsAg}$-negative

\begin{tabular}{|c|c|c|c|c|c|c|c|c|}
\hline $\begin{array}{l}\text { Patient } \\
\text { No. }\end{array}$ & $\begin{array}{l}\text { Sex/ } \\
\text { Age }\end{array}$ & Subtype/ISS & $\begin{array}{l}\text { Treatment lines/ } \\
\text { Response }\end{array}$ & $\begin{array}{l}\text { Hepatitis B } \\
\text { markers before } \\
\text { treatment/ } \\
\text { Prophylaxis }\end{array}$ & $\begin{array}{l}\text { Time to } \\
\text { reactivation } \\
\text { after bortezomib } \\
\text { withdrawal } \\
\text { (months) }\end{array}$ & $\begin{array}{l}\text { Hepatitis B } \\
\text { markers after } \\
\text { reactivation }\end{array}$ & $\begin{array}{l}\text { Antiviral } \\
\text { treatment/ } \\
\text { Response }\end{array}$ & $\begin{array}{l}\text { OS/ } \\
\text { Outcome }\end{array}$ \\
\hline 1 & $\mathrm{M} / 67$ & IgALambda/I & $\begin{array}{l}\text { VAD, Vel-Dex, } \\
\text { ASCT/PR }\end{array}$ & $\begin{array}{l}\text { HBsAg-, } \mathrm{HBeAg}^{-}, \\
\text {AntiHBeAg-, } \\
\text { AntiHBc-, } \\
\text { AntiHBS+/- }\end{array}$ & 23 & $\begin{array}{l}\mathrm{HBsAg+}, \\
\text { HBeAg+, } \\
\text { AntiHBeAg-, } \\
\text { AntiHBc+, } \\
\text { AntiHBs- }\end{array}$ & $\begin{array}{l}\text { Tenofovir/ } \\
\text { HBV DNA- }\end{array}$ & 41/Exitus \\
\hline 2 & $\mathrm{M} / 61$ & IgGKappa/II & VCD, ASCT/VGPR & $\begin{array}{l}\mathrm{HBsAg}+, \mathrm{HBeAg}+\text {, } \\
\text { AntiHBeAg-, } \\
\text { AntiHBc-, } \\
\text { AntiHBS+/ } \\
\text { Tenofovir }\end{array}$ & 7 & $\begin{array}{l}\text { HBsAg+, } \\
\text { HBeAg+, } \\
\text { AntiHBeAg-, } \\
\text { AntiHBc+, } \\
\text { AntiHBs- }\end{array}$ & $\begin{array}{l}\text { Tenofovirl } \\
\text { HBV DNA } \\
\text { decreased }\end{array}$ & 8/Alive \\
\hline 3 & $\mathrm{M} / 45$ & IgGKappa/II & $\begin{array}{l}\text { VAD, Vel- } \\
\text { Dex, ASCT, } \\
\text { Lenalidomide, } \\
\text { VCD, Benda- } \\
\text { Dex, ASCT, } \\
\text { Thalidomide/ } \\
\text { Progression } \\
\end{array}$ & $\begin{array}{l}\text { HBsAg-, HBeAg-, } \\
\text { AntiHBeAg-, } \\
\text { AntiHBc-, } \\
\text { AntiHBS+/- }\end{array}$ & 5 & $\begin{array}{l}\text { HBsAg+, } \\
\text { HBeAg+, } \\
\text { AntiHBeAg-, } \\
\text { AntiHBc+, } \\
\text { AntiHBs- }\end{array}$ & $\begin{array}{l}\text { Tenofovir/ } \\
\text { HBV DNA- }\end{array}$ & 50/Alive \\
\hline 4 & $F / 66$ & IgКарра/II & VCD/VGPR & $\begin{array}{l}\mathrm{HBsAg}+, \mathrm{HBeAg}+, \\
\text { AntiHBeAg-, } \\
\text { AntiHBc-, } \\
\text { AntiHBS+/ } \\
\text { Tenofovir }\end{array}$ & 7 & $\begin{array}{l}\text { HBsAg+, } \\
\text { HBeAg+, } \\
\text { AntiHBeAg-, } \\
\text { AntiHBc+, } \\
\text { AntiHBs- }\end{array}$ & $\begin{array}{l}\text { Tenofovirl } \\
\text { HBV DNA } \\
\text { decreased }\end{array}$ & 8/Alive \\
\hline 5 & $F / 62$ & IgGkappa/III & VCD/PR & $\begin{array}{l}\mathrm{HBsAg}+, \mathrm{HBeAg}+, \\
\text { AntiHBeAg-, } \\
\text { AntiHBc-, } \\
\text { AntiHBS+/ } \\
\text { Lamivudine }\end{array}$ & - & $\begin{array}{l}\text { HBsAg+, } \\
\text { HBeAg+, } \\
\text { AntiHBeAg-, } \\
\text { AntiHBc+, } \\
\text { AntiHBs- }\end{array}$ & $\begin{array}{l}\text { Lamivudine/ } \\
\text { NA }\end{array}$ & 2/Exitus \\
\hline 6 & $F / 66$ & Kappa/I & $\begin{array}{l}\text { VAD, ASCT, Vel- } \\
\text { Dex, Len-Dex/ } \\
\text { VGPR }\end{array}$ & $\begin{array}{l}\text { HBsAg-, } \mathrm{HBeAg}^{-}, \\
\text {AntiHBeAg-, } \\
\text { AntiHBc-, } \\
\text { AntiHBS+/- }\end{array}$ & 5 & $\begin{array}{l}\text { HBsAg+, } \\
\text { HBeAg+, } \\
\text { AntiHBeAg-, } \\
\text { AntiHBc-, } \\
\text { AntiHBs- }\end{array}$ & $\begin{array}{l}\text { Lamivudine/ } \\
\text { HBV DNA } \\
\text { decreased }\end{array}$ & 15/Alive \\
\hline \multicolumn{9}{|c|}{$\begin{array}{l}\text { ASCT: Autologous stem cell transplantation, Anti-HBc: hepatitis B core antibody, AntiHBe: hepatitis B e-antibody, Anti-HBs: hepatitis B surface antibody, Benda: bendamustine, CR } \\
\text { complete remission, Cy-Dex: cyclophosphamide + dexamethasone, DCEP: dexamethasone + cyclophosphamide + etoposide + cisplatin, HBsAg: hepatitis B surface antigen, HBeAg: } \\
\text { hepatitis B e-antigen, Len-Dex: lenalidomide + dexamethasone, MPT: melphalan + prednisolone + thalidomide, VCD: bortezomib + cyclophosphamide + dexamethasone, VAD: } \\
\text { vincristine + doxorubicin + dexamethasone, Vel-Dex: bortezomib + dexamethasone, VMP: bortezomib + melphalan + prednisolone, VGPR: very good partial remission. }\end{array}$} \\
\hline
\end{tabular}


patients. This finding suggests a close follow-up strategy in $\mathrm{HBsAg}$-positive patients as well as $\mathrm{HBsAg}$-negative but anti$\mathrm{HBC}-$, HBeAg-, or anti-HBe-positive MM patients, plus early initiation of active antiviral therapy.

\section{Ethics}

\section{Ethics Committee Approval: N/A.}

Informed Consent: N/A.

\section{Authorship Contributions}

Surgical and Medical Practices: P.A.A., E.A., M.B., R.i.; Concept: P.A.A., E.A., M.B.; Design P.A.A., E.A., M.B.; Data Collection or Processing: P.A.A., E.A., M.Y.; Analysis or Interpretation: P.A.A., E.A., M.Y.; Literature Search: P.A.A., E.A.; Writing: P.A.A., E.A., M.B., R.i.

Conflict of Interest: The authors of this paper have no conflicts of interest, including specific financial interests, relationships, and/or affiliations relevant to the subject matter or materials included.

\section{References}

1. Ergunay K, Balaban Y, Cosgun E, Alp A, Simsek H, Sener B, Tatar G, Hascelik G. Epidemiological trends in HBV infections at a reference centre in Turkey: an 11-year retrospective analysis. Ann Hepatol 2012;11:672678.

2. Akarca US. Chronic hepatitis B. A guide to diagnosis, approach, management, and follow-up 2007, Turkish Association for the Study of the Liver. Turkish J Gastroenterol 2008;19:207-230.

3. Dervite I, Hober D, Morel P. Acute hepatitis B in a patient with antibodies to hepatitis $B$ surface antigen who was receiving rituximab. N Engl J Med 2001;344:68-69.

4. Hui CK, Cheung WW, Zhang HY, Au WY, Yueng YH, Leung AY, Leung N, Luk JM, Lie AK, Kwong YL, Liang R, Lau GK. Kinetics and risk of de novo hepatitis $\mathrm{B}$ infection in $\mathrm{HBsAg}$-negative patients undergoing cytotoxic chemotherapy. Gastroenterology 2006;131:59-68.

5. Totani $H$, Kusumoto $S$, Ishida $T$, Masuda $A$, Yoshida $T$, Ito $A$, Ri M, Komatsu

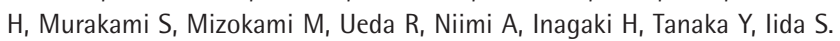
Reactivation of hepatitis B virus (HBV) infection in adult T-cell leukemia lymphoma patients with resolved HBV infection following systemic chemotherapy. Int J Hematol 2015;101:398-404.

6. Cheng AL, Hsiung CA, Su IJ, Chen PJ, Chang MC, Tsao CJ, Kao WY, Uen WC, Hsu CH, Tien HF, Chao TY, Chen LT, Whang-Peng J; Lymphoma Committee of Taiwan Cooperative Oncology Group. Steroid-free chemotherapy decreases risk of hepatitis B virus (HBV) reactivation in HBV-carriers with lymphoma. Hepatology 2003;37:1320-1328.

7. Yeo W, Chan TC, Leung NW, Lam WY, Mo FK, Chu MT, Chan HL, Hui EP, Lei KI, Mok TS, Chan PK. Hepatitis B virus reactivation in lymphoma patients with prior resolved hepatitis $B$ undergoing anticancer therapy with or without rituximab. J Clin Oncol 2009;27:605-611.

8. Locasciulli A, Bruno B, Alessandrino EP, Meloni G, Arcese W, Bandini G, Cassibba V, Rotoli B, Morra E, Majolino I, Alberti A, Bacigalupo A; Italian Cooperative Group for Blood and Marrow Transplantation. Hepatitis reactivation and liver failure in haemopoietic stem cell transplants for hepatitis B virus (HBV)/hepatitis C virus (HCV) positive recipients: a retrospective study by the Italian group for blood and marrow transplantation. Bone Marrow Transplant 2003;31:295-300.
9. Kim HY, Kim W. Chemotherapy-related reactivation of hepatitis B infection: updates in 2013. World J Gastroenterol 2014;20:14581-14588.

10. Idilman $R$, Arat M. Evaluation and management of hepatitis $B$ virus infection in hematopoietic stem cell transplantation: before and after transplantation. Expert Rev Anti Infect Ther 2011;9:641-652.

11. Yeo W, Chan PK, Zhong S, Ho WM, Steinberg JL, Tam JS, Hui P, Leung NW, Zee B, Johnson PJ. Frequency of hepatitis B virus reactivation in cancer patients undergoing cytotoxic chemotherapy: a prospective study of 626 patients with identification of risk factors. J Med Virol 2000;62:299-307.

12. Hoofnagle JH. Reactivation of hepatitis B. Hepatology 2009;49(5 Suppl):156-165.

13. European Association for the Study of the Liver. EASL clinical practice guidelines: management of chronic hepatitis B virus infection. J Hepatol 2012;57:167-185.

14. Reddy KR, Beavers KL, Hammond SP, Lim JK, Falck-Ytter YT; American Gastroenterological Association Institute. American Gastroenterology Association Institute guideline on the prevention and treatment of hepatitis B virus reactivation during immunosuppressive drug therapy. Gastroenterology 2015;148:215-219.

15. Kumar SK, Callander NS, Alsina M, Atanackovic D, Biermenn JS, Chandler JC, Cornell RF, Costello C, Efebera Y, Faiman M, Godby K, Hillengass J, Holmberg L, Holstein S, Htut M, Huff CA, Kang Y, Landren O, Liedtke M, Malek E, Martin T, Omel J, Raje N, Singhal S, Goldstein-Stockerl K, Tan C, Wever C. NCCN Guidelines Version 3.2017. Multiple Myeloma. Plymouth Meeting, National Comprehensive Cancer Network, 2017.

16. Dimopoulos MA, Terpos E, Niesvizky R. How lenalidomide is changing the treatment of patients with multiple myeloma. Crit Rev Oncol Hematol 2013;88(Suppl 1):23-35.

17. Goldberg R, Smith E, Bell S, Thompson A, Desmond PV. Bortezomib monotherapy in patients with multiple myeloma is associated with reactivation of hepatitis B. Intern Med J 2013;43:835-836.

18. Tanaka H, Sakuma I, Hashimoto S, Takeda T, Sakai S, Takagi T, Shimura T, Nakaseko C. Hepatitis B reactivation in a multiple myeloma patient with resolved hepatitis $\mathrm{B}$ infection during bortezomib therapy: case report. J Clin Exp Hematop 2012;52:67-69.

19. Beysel S, Yegin ZA, Yağci M. Bortezomib-associated late hepatitis B reactivation in a case of multiple myeloma. Turk J Gastroenterol 2010;21:197-198.

20. Lok AS, Liang RH, Chiu EK, Wong KL, Chan TK, Todd D. Reactivation of hepatitis $B$ virus replication in patients receiving cytotoxic therapy. Report of a prospective study. Gastroenterology 1991;100:182-188.

21. Huang B, Li J, Zhou Z, Zheng D, Liu J, Chen M. High prevalence of hepatitis $B$ virus infection in multiple myeloma. Leuk Lymphoma 2012;53:270-274.

22. Idilman R. Lamivudine prophylaxis in HBV carriers with haematooncological malignancies who receive chemotherapy. J Antimicrob Chemother 2005;55:828-831.

23. Lok AS, Liang RH, Chiu EK, Wong KL, Chan TK, Todd D. Reactivation of hepatitis B virus replication in patients receiving cytotoxic therapy: report of a prospective study. Gastroenterology 1991;100:182-188.

24. Loomba R, Rowley A, Wesley R, Liang TJ, Hoofnagle JH, Pucino F, Csako G. Systematic review: the effect of preventive lamivudine on hepatitis $B$ reactivation during chemotherapy. Ann Intern Med 2008;148:519-528.

25. Idilman R, Arat M, Soydan E, Törüner M, Soykan I, Akbulut $H$, Arslan O, Ozcan M, Türkyilmaz AR, Bozdayi M, Karayalçin S, Van Thiel DH, Ozden A, Beksaç M, Akan $\mathrm{H}$. Lamivudine prophylaxis for prevention of chemotherapy-induced hepatitis $B$ virus reactivation in hepatitis $B$ virus carriers with malignancies. J Viral Hepat 2004;11:141-147.

26. Idilman R. Duration of lamivudine prophylaxis in inactive hepatitis B virus carriers with hemato/oncological malignancies who receive chemotherapy. Gut 2006;55:1208-1209. 
27. Kusumoto S, Tanaka Y, Mizokami M, Ueda R. Reactivation of hepatitis B virus following systemic chemotherapy for malignant lymphoma. Int J Hematol 2009;90:13-23.

28. Lee JY, Lim SH, Lee MY, Kim H, Sinn DH, Gwak GY, Choi MS, Lee JH, Jung CW, Jang JH, Kim WS, Kim SJ, Kim K. Hepatitis B reactivation in multiple myeloma patients with resolved hepatitis B undergoing chemotherapy. Liver Int 2015;35:2363-2369.

29. Mya DH, Han ST, Linn YC, Hwang WY, Goh YT, Tan DC. Risk of hepatitis B reactivation and the role of novel agents and stem-cell transplantation inmultiplemyeloma patients with hepatitis B virus (HBV) infection. Ann Oncol 2012;23:421-426.

30. Li J, Huang B, Li Y, Zheng D, Zhou Z, Liu J. Hepatitis B virus reactivation in patients with multiple myeloma receiving bortezomib-containing regimens followed by autologous stem cell transplant. Leuk Lymphoma 2015;56:1710-1717.

31. Blanco $B$, Pérez-Simón JA, Sánchez-Abarca LI, Carvajal-Vergara $X$, Mateos J, Vidriales B, López-Holgado N, Maiso P, Alberca M, Villarón E, Schenkein D, Pandiella A, San Miguel J. Bortezomib induces selective depletion of alloreactive T lymphocytes and decreases the production of Th1 cytokines. Blood 2006;107:3575-3583.
32. König C, Kleber M, Reinhardt H, Knop S, Wasch R, Engelhardt M. Incidence, risk factors and implemented prophylaxis of varicella zoster virus infection, including complicated varicella zoster virus and herpes virus infections in lenalidomide-treated multiple myeloma patients. Ann Hematol 2014;93:479-484.

33. Kumagai K, Takagi T, Nakamura S, Sawada U, Kura Y, Kodama F, Shimano S, Kudoh I, Nakamura H, Sawada K, Ohnoshi T. Hepatitis B virus carriers in the treatment of malignant lymphoma: an epidemiological study in Japan. Ann Oncol 1997;8(Suppl 1):107-109.

34. Uhm JE, Kim K, Lim TK, Park BB, Park S, Hong YS, Lee SC, Hwang IG, Koh KC, Lee MH, Ahn JS, Kim WS, Jung CW, Kang WK. Changes in serologic markers of hepatitis B following autologous hematopoietic stem cell transplantation. Biol Blood Marrow Transplant 2007;13:463-468.

35. Yoshida $T$, Kusumoto $S$, Inagaki A, Mori F, Ito A, Ri M, Ishida T, Komatsu $H_{\text {, }}$ lida S, Sugauchi F, Tanaka Y, Mizokami M, Ueda R. Reactivation of hepatitis $B$ virus in HBsAg-negative patients with multiple myeloma: two case reports. Int J Hematol 2010;91:844-849. 